\section{The Journal of Politics}

Published for the Southern Political Science Association

\section{Editors}

Jan E. Leighley, American University, USA

William Mishler, University of Arizona, USA

The Journal of Politics, a leading general journal of political science, publishes path-breaking research in all subfields from all parts of the world including but not limited to: American politics; comparative politics; formal theory; international relations; methodology; political theory; public administration; and public policy.

\section{Price information}

is available at: http://journals.cambridge.org/jop

\section{Free email alerts}

Keep up-to-date with new material - sign up at http://journals.cambridge.org/alerts

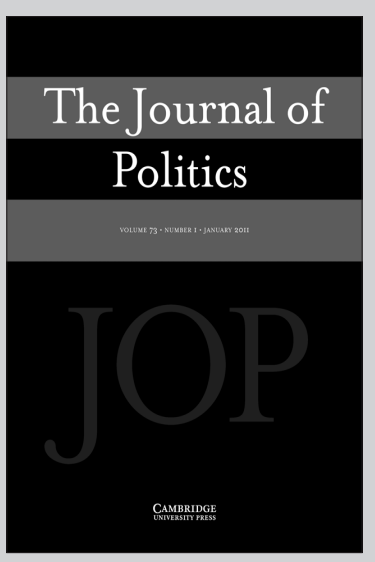

The Journal of Politics

is available online at:

http://journals.cambridge.org/jop

To subscribe contact

Customer Services

in Cambridge:

Phone +44 (0)1223 326070

Fax +44 (0)1223 325150

Email journals@cambridge.org

in New York:

Phone +1 (845) 3537500

$\mathrm{Fax}+1$ (845) 3534141

Email

subscriptions_newyork@cambridge.org 


\section{CAMBRIDGE}

\section{OUTSTANDING SCHOLARSHIP from CAMBRIDGE}

\section{Cambridge Studies in \\ International Relations}

The Great Powers and the International System Systemic Theory in Empirical Perspective Bear F. Braumoeller \$90.00: Hb: 978-1-107-00541-9 \$29.99: Pb: 978-1-107-65918-6: $272 \mathrm{pp}$.

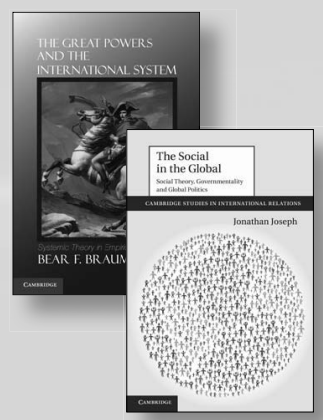

The Social in the Global Social Theory, Governmentality and Global Politics Jonathan Joseph \$99.00: Hb: 978-1-107-02290-4: $320 \mathrm{pp}$.

\section{Special Responsibilities}

Global Problems and

American Power

Mlada Bukovansky, Ian Clark, Robyn Eckersley, Richard Price,

Christian Reus-Smit, and Nicholas J. Wheeler

\$85.00: Hb: 978-1-107-02135-8 \$29.99: Pb: 978-1-107-69169-8: $302 \mathrm{pp}$.

\section{Proconsuls}

Delegated Political-Military Leadership from Rome to America Today

Carnes Lord

\$99.00: Hb: 978-1-107-00961-5 \$29.99: Pb: 978-0-521-25469-4: $256 \mathrm{pp}$.

War, Guilt, and World Politics after World War II Thomas U. Berger \$95.00: Hb: 978-1-107-02160-0 \$29.99: Pb: 978-1-107-67495-0: $272 \mathrm{pp}$.

The Challenge of Grand Strategy The Great Powers and the Broken Balance between the World Wars

Edited by

Jeffrey W. Taliaferro, Norrin M. Ripsman, and Steven E. Lobell

\$99.00: Hb: 978-1-107-02252-2: $360 \mathrm{pp}$.

\section{Russia and the West} from Alexander to Putin Honor in International Relations Andrei P. Tsygankov \$99.00: Hb: 978-1-107-02552-3: $324 \mathrm{pp}$.

Small Arms Survey 2012 Moving Targets

Small Arms Survey, Geneva Small Arms Survey \$99.00: Hb: 978-0-521-19714-4 \$34.99: Pb: 978-0-521-14687-6: $376 \mathrm{pp}$.
Amnesty in the Age of Human Rights Accountability

Comparative and International Perspectives

Edited by Francesca Lessa and Leigh A. Payne

\$110.00: Hb: 978-1-107-02500-4 \$39.99: Pb: 978-1-107-61733-9: $456 \mathrm{pp}$.

\section{International Law, US Power}

The United States' Quest for Legal Security

Shirley V. Scott

\$99.00: Hb: 978-1-107-01672-9 \$30.00: Pb: 978-1-107-60259-5: $292 \mathrm{pp}$.

\section{The Cambridge Companion to International Law}

Edited by James Crawford and Martti Koskenniemi

Cambridge Companions to Law

\$115.00: Hb: 978-0-521-19088-6 \$45.00: Pb: 978-0-521-14308-0: $484 \mathrm{pp}$.

\section{Hugo Grotius}

On the Law of

War and Peace

Student Edition

Edited by Stephen C. Neff \$99.00: Hb: 978-0-521-19778-6 \$42.00: Pb: 978-0-521-12812-4 $552 \mathrm{pp}$.

Prices subject to change. 


\section{CAMBRIDGE}

\section{JOURNALS}

\section{A World of Quality Scholarship.}

International Relations Journals from Cambridge University Press

WORLD POLITICS

A Quarterly foumal of

International Relations

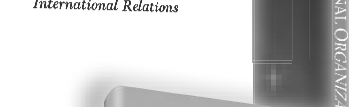

\section{Global Constitutionalism}

journals.cambridge.org/ir
Review of

International

Studies
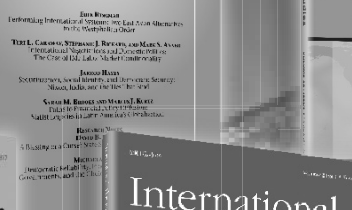
Theory

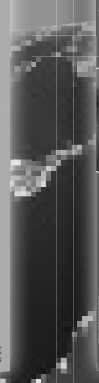

CAvaringl

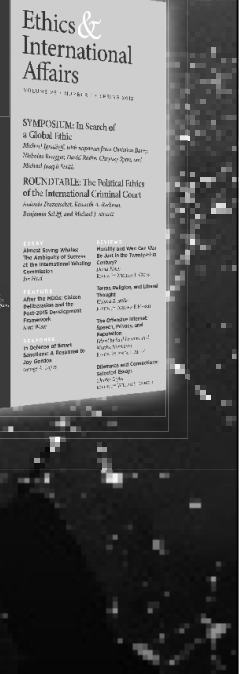




\section{International Organization}

Volume 66 Number 3 Summer 2012

Subscription Information: IO International Organization (ISSN 0020-8183) is published quarterly (winter, spring, summer, and fall) by Cambridge University Press for the IO Foundation. Annual subscription rates for Volume 66 (2012): Institutional subscription rates, print and online: US \$273 in the USA, Canada, and Mexico; UK £167 + VAT elsewhere. Institutional subscription rate, online only: US \$228 in the USA, Canada, and Mexico; UK $£ 143$ + VAT elsewhere. Individual subscription rate, print and online: US \$58 in the USA, Canada, and Mexico; UK £33 + VAT elsewhere. Single part rates (print only): US \$75 in the USA, Canada, and Mexico; UK $£ 45+$ VAT elsewhere. For an additional \$50 annual fee, individual subscribers can access $I O$ back volumes 1-49, available online from JSTOR. Prices include surface postage. Periodicals postage paid at New York, NY, and additional mailing offices. Postmaster: Send address changes to International Organization, Cambridge University Press, 100 Brook Hill Drive, West Nyack, NY 10994-2133, USA.

Abstracting Information: IO International Organization is abstracted or indexed in the following: Academic Abstracts, ABC Pol Sci, America: History and Life, Communication Abstracts, Current Contents/Social \& Behavioral Sciences, Current Law Index, Deep Sea Research \& Oceanographic Abstracts, Energy Research Abstracts, Expanded Academic Index, Future Survey, Historical Abstracts, Human Rights Internet Reporter, INIS Atomindex, Index of Economics Articles, International Bibliography of Economics (also in IBSS), International Bibliography of Periodical Literature, International Bibliography of the Social Sciences/Political Science, International Labour Documentation, International Political Science Abstracts, Journal of Economic Literature, Key to Economic Science, Legal Research Index, Magazine Index (Information Access Company), Middle East: Abstracts and Index, Public Affairs Information Service/PAIS, Recently Published Articles, Rural Recreation and Tourism, SCIMP (Selective Cooperative Index of Management Periodicals), Social Sciences Citation Index, Social Sciences Index, Social Science Source, Sociological Abstracts, World Affairs Online (WAO), accessible via the portal IREON, World Agricultural Economics \& Rural Sociology Abstracts.

Advertising and Mailing List Rental: Contact: Cambridge University Press, 32 Avenue of the Americas, New York, NY 10013-2473, USA; phone: (212) 337-5000; e-mail: journals@ cambridge.org.

Photocopying Information for Users in the USA: The Item-Fee code for this publication (0020-8183/10 \$12.50) indicates that copying for internal or personal use beyond that permitted by Sec. 107 or 108 of the US Copyright Law is authorized for users duly registered with the Copyright Clearance Center (CCC) Transaction Reporting Service, provided that the appropriate remittance per article is paid directly to: CCC, 222 Rosewood Drive, Danvers, MA 01923.

Rights and Permissions: All inquiries concerning rights and permissions should be sent to Rights and Permissions Department, Cambridge University Press, 32 Avenue of the Americas, New York, NY 10013-2473, USA; phone: (212) 337-5000; e-mail: permissions@ cambridge.org. 


\section{A Journal of \\ Political and \\ Economic Affairs}

\section{Edited at The Department of Political Science, University of Wisconsin Published by Cambridge University Press}

